\title{
IDENTIFICATION AND COMPONENT ANALYSIS OF TRITERPENOIDS IN MONARDA FISTULOSA L. AND OCIMUM AMERICANUM L. (Lamiaceae) AERIAL PARTS
}

\author{
(C) M. Shanaida, O. Golembiovska
}

Незважаючи на прогрес у створенні синтетичних препаратів, ліки рослинного походження не втрачають своєї актуальності до сьогодні. Тритерпеноїди є досить поширеною групою біологічно активних сполук рослин та виявляють широкий діапазон фармакологічної активності. Лікарські рослини родини Ясноткові (Lатіасеае) здатні накопичувати пентациклічні тритерпенові сполуки, які виявляють антиоксидантну, протизапальну, гепатопротекторну, протипухлинну та антимікробну дію. На сьогодні в Украӥні інтродуковано ијілий ряд нових маловивчених видів родини, серед яких - монарда трубчаста (Monarda fistulosa L.) та васильки американські (Ocimum americanum L.).

Метою даного дослідження була ідентифікація, встановлення складу та компонентного вмісту тритерпенових сполук в надземній частині монарди трубчастої (M. fistulosa) i васильків американських (O. атегісапит) за умови їх культивування на територї Західного Поділля.

Методи. Для встановлення наявності групи тритерпеноїдів в рослинній сировині використано пінну пробу, реакцію осадження та кольорову реакцію; для визначення компонентного вмісту тритерпенових сполук застосовано метод високоефективної рідинної хроматографії (ВЕРХ); визначення проводили на рідинному хроматографi Shimadzu LC 20 Prominence.

Результати. Наявність тритерпенових сполук було встановлено за допомогою пінної проби, реакцій ідентифікації та ВЕРХ. Ефективне екстрагування тритерпенових сполук з трави досліджуваних рослин було досягнуте з використанням $96 \%$ та 70 \% етанолу. Використання ВЕРХ-аналізу дозволило встановити істотні відмінності у вмісті урсолової, еускафової, торментинової та олеанолової кислот, бетуліну та лупеолу в надземній частині досліджуваних рослин. Домінуючими компонентами трави М. fistulosa та O. атегісапит були урсолова та еускафова кислоти.

Висновки. На основі проведених досліджень було ідентифіковано та встановлено компонентний вміст 6 тритерпеноїдів у надземній частині M. fistulosa та O. атеricanит. Отримані дані можна використати при плануванні фармакологічних досліджень та в хемотаксономії родини Lатіасеае

Ключові слова: Lamiaceae; Monarda fistulosa; Ocimum americanum; BEPX; тритерпеноїди, надземна частина, етанольний витяг

\section{Introduction}

Despite the progress in the creation of synthetic drugs, herbal medicines do not lose their relevance nowadays. Phytopreparations are, as a rule, multicomponent composition, and, consequently, multipurpose, as in addition to the effect on target organs, the regulatory systems of the organism are also activated [1]. Medicinal plants with essential oils are an important source of medical and prophylactic treatments from ancient times to the present day, in connection with which scientists are interested in their phytochemical research $[2,3]$.

2. Formulation of the problem in a general way, the relevance of the theme and its connection with important scientific and practical issues

Medicinal plants of the Lamiaceae family containing essential oils have long been used in scientific and folk medicine as a source of therapeutic and prophylactic medicines [3, 4]. To date, a number of newly unknown species of the family [5] have been introduced in Ukraine, among them - Bee balm (Monarda fistulosa L.) and American basil (Ocimum americanum L.). The above-ground parts of these plants are used in folk medicine of different countries, but they are not used in officinal medicine [4]. It is important that, along with the therapeutic and preventive action, both plants have good spice and taste qualities, which opens the possibility of their wide application in the manufacture of galenic preparations.

3. Analysis of recent studies and publications in which a solution of the problem are described and to which the author refers

A rather important group of compounds of secondary synthesis, which have a wide range of biological activity, are triterpenoids. According to various authors [6-8], representatives of the Lamiaceae family accumulate mainly ursane and oleanane derivatives that exhibit anti-inflammatory, antioxidant, hepatoprotective, antitumor, antiviral and antimicrobial properties. It is worth noting that some of these biological properties also show other compounds of secondary synthesis, previously found in various organs of plants of this family [9-11].

4. The field of research considering the general problem, which is described in the article

An important stage in the pharmacological research of poorly-studied, but promising species of medicinal plants is the analysis of compounds of secondary synthesis, which include triterpenoids. The peculiarities 
of the accumulation of triterpene compounds in the herb of the non-fictional medicinal plants of the family Lamiaceae, in particular M. fistulosa and O. americanum, which have been introduced in Ukraine in recent years, remain not studied.

\section{Formulation of goals (tasks) of article}

The purpose of this work was to identify the composition and component content of triterpene compounds in the aboveground parts of $M$. fistulosa and O. americanum (under the condition of their cultivation on the territory of Western Podillya, Ukraine).

\section{Presentation of the main research material} (methods and objects) with the justification of the results

Extraction of triterpenic saponins from the herb of $M$. fistulosa and $O$. americanum was carried out using ethanol of various concentrations $(50 \%, 70 \%$ and $96 \%$ ), which is considered an effective and environmentally justified extractive agent $[5,7]$. The particles of $1 \mathrm{~mm}$ herb of investigated plants $(5.0 \mathrm{~g})$ were placed in a $250 \mathrm{ml}$ circular flask, and $100 \mathrm{ml}$ of ethanol of appropriate concentration was added. At first, ethanol-filled raw material was infused at room temperature for 3 hours, stirring periodically. Further, extraction was performed on a water heater at boiling point of the extractive agent for 1 hour. The cooled extract was filtered through a paper filter in a $100 \mathrm{ml}$ volumetric flask and, if necessary, adjusted to the label with the appropriate extractant. An aliquot of each extract was evaporated to a dry residue and used for HPLC analysis. The remains were evaporated to $1 / 4-1 / 5$ of the original volume and used to identify triterpene saponins.

Identification of triterpenoids (according to [12])

Foam test. Approximately $1 \mathrm{ml}$ of extract for identification was diluted to $5 \mathrm{ml}$ with purified water, closed with a stopper and vigorously shaken for $1 \mathrm{~min}$. The formation of stable foam indicated the presence of triterpene saponins.

Sedimentation reaction. To $1 \mathrm{ml}$ of the extract for identification, 3-4 drops of $10 \%$ lead (II) acetate solution were added. The appearance of sediment indicated the presence of triterpene compounds.

Colour reaction. To $1 \mathrm{ml}$ of the extract for identification, 1 drop of $10 \%$ solution of copper (II) sulphate and $1 \mathrm{ml}$ of concentrated sulfuric acid solution were added, after which the mixture was carefully heated. The appearance of a blue-green colour indicated the presence of triterpene saponins.

HPLC analysis of triterpenoids (in accordance with $[13,14])$

Investigation of the qualitative composition and quantitative content of triterpene compounds by the HPLC method was carried out on a liquid chromatograph Shimadzu LC 20 Prominence in a modular system equipped with a four-channel LC 20AD pump, a thermostat of columns 20A, an automatic sampler SIL 20A, SPDM 20A diode-matrix detector and ChemStation LC 20 A X-Bridge C18 column of $150 \mathrm{~mm} \times 4.6 \mathrm{~mm}$, a particle size of $5 \mu \mathrm{m}$ (Waters, Ireland) was used; column temperature $-30{ }^{\circ} \mathrm{C}$; detection wavelength $-205 \mathrm{~nm}$; flow rate of the mobile phase $-1.0 \mathrm{ml} / \mathrm{min}$; volume of the injected sample $-20 \mu \mathrm{l}$.

Moving phase: methanol and $0.2 \%$ ammonium acetate solution $(\mathrm{pH}=6.75)$ in the ratio 80:20; elution mode isocratic. Identification of the components was carried out in accordance with the time of maintenance and compliance with the UV spectra of the substancesstandards (oleanolic, ursolic, tormentic, and euscaphic acids, betulin and lupeol), which were determined in the range $190-800 \mathrm{~nm}$.

Results and discussion. In the extracts of $M$. fistulosa and $O$. americanum raw materials obtained on the basis of high concentrations of ethanol (70\% and $96 \%)$, a positive result was found regarding the presence of triterpene compounds in the use of the foaming test, as well as the colour and sedimentation reactions.

Based on the data of the analysis of UV spectra of standard models of triterpene compounds and investigated extracts, absorption peaks were found in the range of wavelengths of 200-210 nm, so their HPLC analysis was carried out at $205 \mathrm{~nm}$. The results of the HPLC analysis of triterpenoids in the herb of the investigated plants are presented in Table 1 and on Fig. 1, 2; 6 compounds were identified.

As can be seen from the results obtained (Table 1, Fig. 1, 2), effective extractants for extracting triterpene compounds from the herbs of the studied plants were $96 \%$ and $70 \%$ ethanol; its $50 \%$ concentration was less effective.

Table 1

Component content of triterpene compounds in the aboveground parts of $M$. fistulosa and O. americanum

\begin{tabular}{|c|c|c|c|c|c|c|}
\hline \multirow{3}{*}{ Component } & \multicolumn{6}{|c|}{ Content, $\%$} \\
\hline & \multicolumn{3}{|c|}{ M. fistulosa } & \multicolumn{3}{|c|}{ O. americanum } \\
\hline & $\begin{array}{c}96 \% \\
\text { ethanol }\end{array}$ & $\begin{array}{c}70 \% \\
\text { ethanol }\end{array}$ & $\begin{array}{c}50 \% \\
\text { ethanol }\end{array}$ & $\begin{array}{c}96 \% \\
\text { ethanol }\end{array}$ & $\begin{array}{c}70 \% \\
\text { ethanol }\end{array}$ & $\begin{array}{l}50 \% \\
\text { ethanol }\end{array}$ \\
\hline \multicolumn{7}{|c|}{ Derivatives of ursane } \\
\hline Ursolic acid & 0.22 & 0.11 & 0.02 & 0.19 & 0.12 & $<0.01$ \\
\hline Euscaphic acid & 0.31 & 0.32 & 0.12 & 0.21 & 0.31 & 0.06 \\
\hline Tormentic acid & 0.03 & 0.04 & $<0.01$ & 0.03 & 0.06 & 0.01 \\
\hline \multicolumn{7}{|c|}{ Derivatives of oleanane } \\
\hline Oleanolic acid & 0.13 & 0.08 & 0.01 & 0.14 & 0.15 & $<0.01$ \\
\hline \multicolumn{7}{|c|}{ Derivatives of lupane } \\
\hline Betulin & 0.09 & 0.11 & 0.05 & 0.06 & 0.1 & 0.03 \\
\hline Lupeol & - & - & - & 0.05 & - & - \\
\hline
\end{tabular}



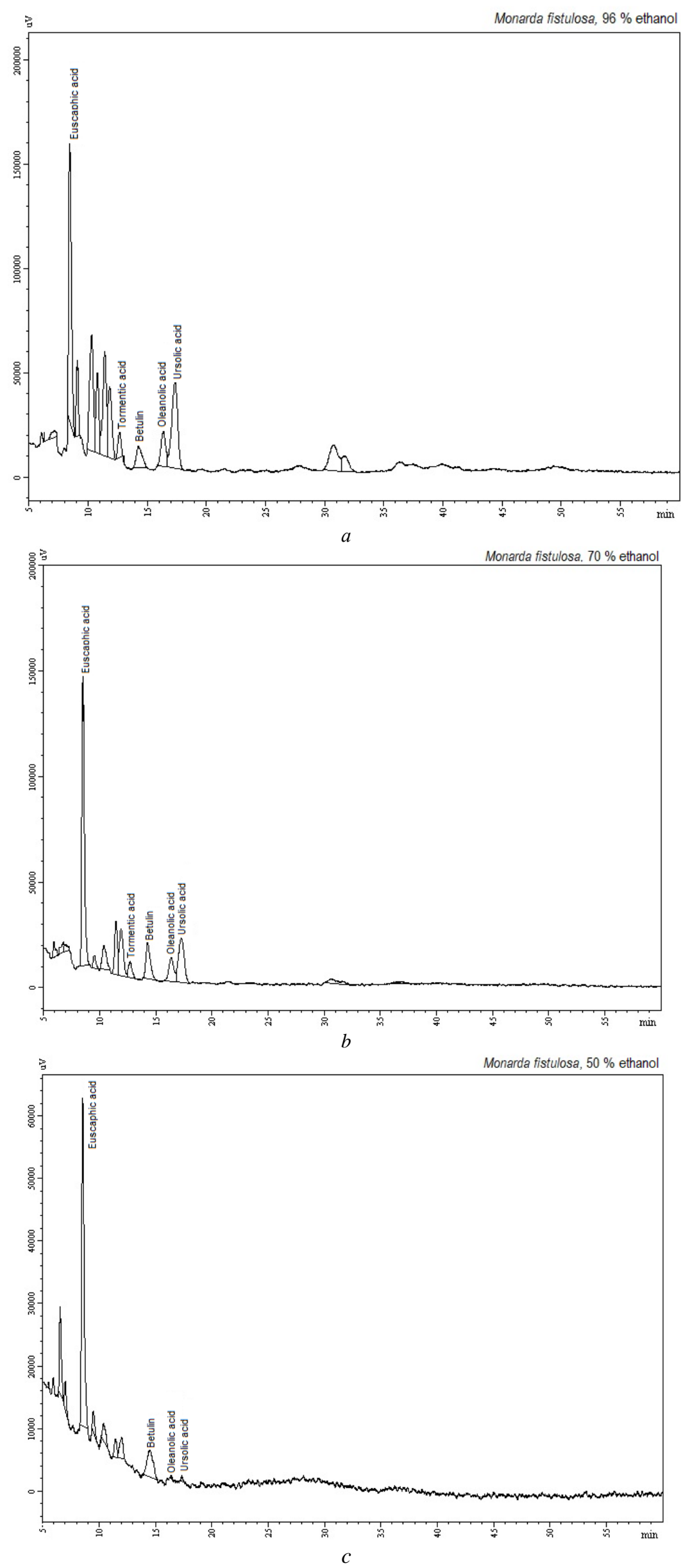

Fig. 1. Chromatogram of $M$. fistulos $a$ herb extracts, obtained using ethanol of various concentrations: $a-96 \%$; $b-70 \% ; c-50 \%$ (at $205 \mathrm{~nm})$ 

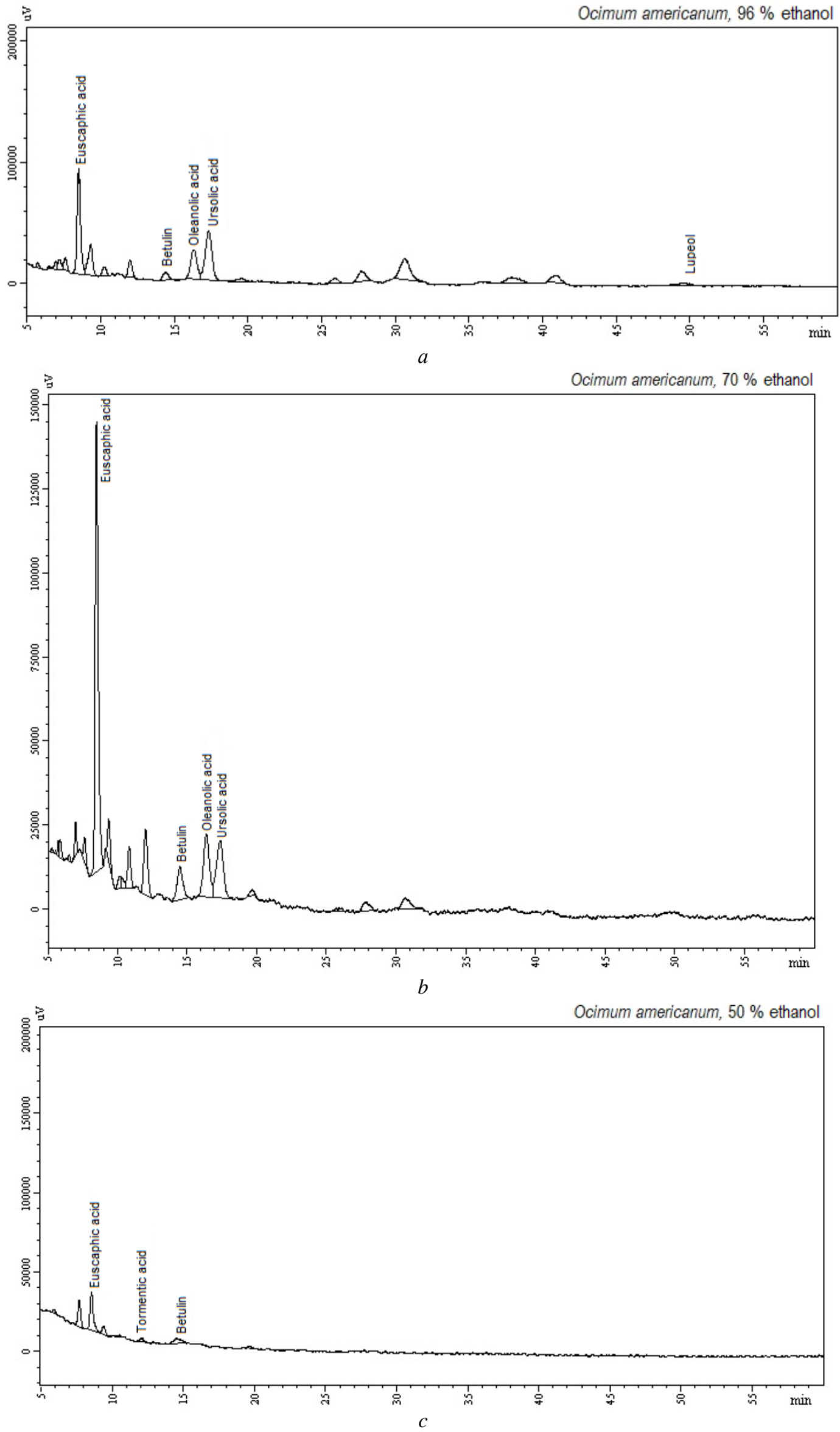

Fig. 2. Chromatogram of the $O$. americanum herb extracts, obtained using ethanol of various concentrations: $a-96 \%$; $b-70 \% ; c-50 \%$ (at $205 \mathrm{~nm}$ ) 
Ursolic and euscaphic acids ( $\alpha$-amine derivatives based on the ursane skeleton - Fig. 3) are the dominant components in $96 \%$ and $70 \%$ of ethanol extracts of both studied plants. As can be seen from Table 1, $96 \%$ ethanol is the optimal extractant for extracting ursolic acid from the herbs of M. fistulosa and $O$. americanum $(0.22 \%$ and $0.19 \%$, respectively), while $70 \%$ ethanol - euscaphic one $(0.32 \%$ and $0.31 \%$, respectively). The obtained results correlate with the literature data for other species of the Lamiaceae family with respect to the domination of the ursane derivatives. Thus, leaves of 8 representatives of the Ocimum genus, which grew on the territory of
Brazil [7], accumulated ursolic acid in the range of $0.29-2.02 \%$; the above-ground bodies of 4 species of the Ocimum genus, harvested in India, accumulated ursolic acid in the range of $0.008-0.296 \%[15,16]$. The content of this compound in the aboveground part of 5 species of plants of the Rosmarinus, Salvia and Satureja genus ranges from 0.09 to $1.6 \%$ [17]. Ursolic acid, which is a fairly common substance in the raw materials of the Lamiaceae family, has antiinflammatory, antioxidant, hepatoprotective, antiviral, antimicrobial and cytostatic properties [6, 8]. The content of tormentic acid in the raw materials of the studied plants is low (Table 1, Fig. 1, 2).

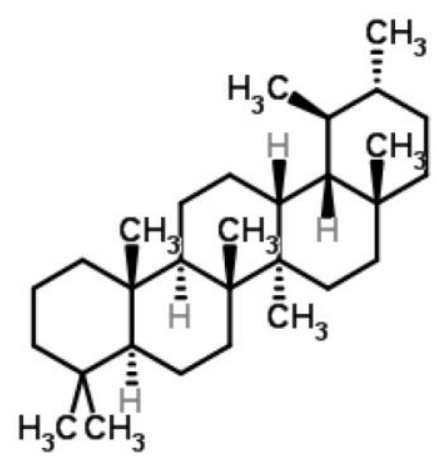

Ursane

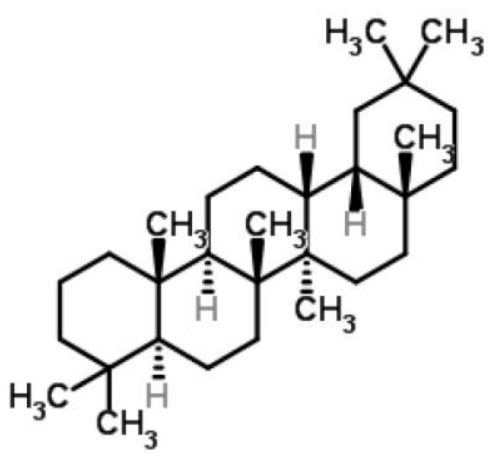

Oleanane

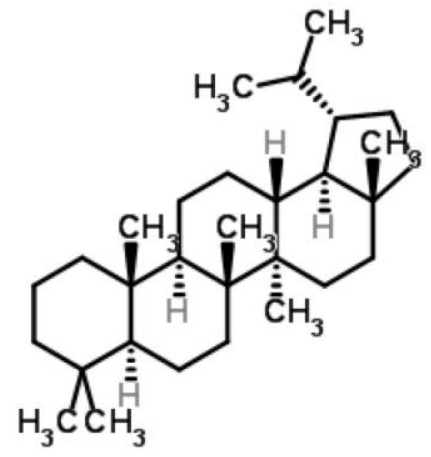

Lupane

Fig. 3. The chemical structure of triterpene compounds, derivatives of which are found in herbs of $M$. fistulosa Ta $O$. americanum

Oleanolic acid (a representative of the $\beta$-aminine group, which is based on the oleanane skeleton - Fig. 3), is usually identified in parallel with ursolic acid in the raw material of many plants of the Lamiaceae family [6, 14]. These triterpenoids are found both in the form of aglycones and in the form of glycosides, and have similar biological properties $[6,8]$. The content of oleanolic acid is higher in the raw material of $O$. americanum in comparison with $M$. fistulosa, regardless of the ethanol concentration used (see Table 1). The obtained results correlate with the data of the literature, according to which [14] the above-ground part of Ocimum gratissimum accumulates $0.14 \%$ of oleanolic acid; the content of this compound in the above-ground parts of the plants of the Rosmarinus, Salvia and Satureja genus ranges from 0.09 to $0.9 \%$ [17].

The best solvent for extraction of betulin (a derivative of a lupane - see Figure 3) from the herb of both plants is $70 \%$ ethanol (see Table 1). Another representative of the lupane group - lupeol - was found in a small amount in only $96 \%$ ethanol extract of the O. americanum herb.

It is known that the content of different groups of biologically active substances in plants has a significant impact on the peculiarities of the climate and soils of the region of growth, the presence of chemotypes, peculiarities of care and preparation, selection of extraction and analysis conditions. It should be noted that the use of HPLC analysis to determine the qualitative composition and quantitative content of triterpene saponins in plants is quite common [13, 15]; some scientists also use the method of gas chromatography after precolomn derivatization [17, 18]. Obviously, all these factors have a certain effect on the content of triterpene compounds in the raw material of O. americanum та M. fistulosa.

\section{Conclusions}

1. It was identified the triterpenoids in ethanoic extracts obtained from herbs of $M$. fistulosa and O. americanum; the components of triterpenoids were determined by the HPLC method.

2. It has been determined that high concentrations of ethanol (96\% and $70 \%$ ) contribute to the more efficient extraction of triterpene compounds from the raw materials of the studied species than $50 \%$ ethanol.

3. The peculiarities of the accumulation of 6 triterpene compounds (ursolic, oleanolic, euscaphic and tormentic acids, as well as betulin and lupeol) in the herb of $M$. fistulosa and $O$. americanum were established under cultivation of plants in the West Podillya (Ukraine). Ursolic and euscaphic acid are the dominant triterpene compounds in the herb of both species. 


\section{References}

1. Multi-Target Drugs: The Trend of Drug Research and Development / Lu J.-J. et. al. // PLoS ONE. 2012. Vol. 7, Issue 6. P. e40262. doi: http://doi.org/10.1371/journal.pone.0040262

2. Development of methods for identification of phenolic compounds in tansy flowers / Zolotaikina M. Yu. et. al. // ScienceRise. 2016. Vol. 4, Issue 4 (21). P. 38-41. doi: http://doi.org/10.15587/2313-8416.2016.67614

3. Likarski roslyny: Entsyklopedychnyi dovidnyk. Kyiv: Vyd-vo "Ukrainska entsyklopediia" im. M. P. Bazhana, 1992. 544 p.

4. Derzhavnyi reiestr likarskykh zasobiv Ukrainy. URL: http://www.drlz.com.ua

5. Katalog zavershennykh nauchnykh razrabotok otdela novykh kul'tur Natsional'nogo botanicheskogo sada im. M. M. Grishko / Rakhmetov D. B. et. al. Kyiv: Nora-Druk, 2003. 76 p.

6. Liu J. Pharmacology of oleanolic acid and ursolic acid // Journal of Ethnopharmacology. 1995. Vol. 49, Issue 2. P. 57-68. doi: http://doi.org/10.1016/0378-8741(95)90032-2

7. Variation of Ursolic Acid Content in Eight Ocimum Species from Northeastern Brazil / Silva M. G. et. al. // Molecules. 2008. Vol. 13, Issue 10. P. 2482-2487. doi: http://doi.org/10.3390/molecules 13102482

8. Sultana N. Clinically useful anticancer, antitumor, and antiwrinkle agent, ursolic acid and related derivatives as medicinally important natural product // Journal of Enzyme Inhibition and Medicinal Chemistry. 2011. Vol. 26, Issue 5. P. 616-642. doi: http://doi.org/10.3109/14756366.2010.546793

9. Tsurkan O. O., Holembiovska O. I., Koliadych O. P. Sukhovershky zvychaini Prunella vulgaris L. - tsinna likarska roslyna (Ohliad literatury) // Fitoterapiia. 2013. Issue 1. P. 51-55.

10. Shanaida M. I., Pokryshko O. V. Antymikrobna aktyvnist efirnykh olii kultyvovanykh predstavnykiv rodyny Lamiaceae Juss // Annals of Mechnikov Institute. 2015. Issue 4. P. 66-69.

11. Shanaida M., Kernychna I., Shanaida Yu. Chromatographic analysis of organic acids, amino acids, and sugars in Ocimum americanum L. // Acta Poloniae Pharmaceutica. Drug Research. 2017. Vol. 74, Issue 2. P. 729-732.

12. Praktikum po farmakognozii / Kovalev V. N. et. al. Kharkiv: Izd-vo NFaU, 2003. 512 p.

13. Chen J. H., Xia Z. H., Tan R. X. High-performance liquid chromatographic analysis of bioactive triterpenes in Perilla frutescens // Journal of Pharmaceutical and Biomedical Analysis. 2003. Vol. 32, Issue 6. P. 1175-1179. doi: http://doi.org/10.1016/ s0731-7085(03)00160-2

14. Development of a validated liquid chromatographic method for the quality control of Prunellae Spica: Determination of triterpenic acids / Lee M. K. et. al. // Analytica Chimica Acta. 2009. Vol. 633, Issue 2. P. 271-277. doi: http://doi.org/ 10.1016/j.aca.2008.12.038

15. Pai S. R., Joshi R. K. Variations in Pentacyclic Triterpenoids in Different Parts of Four Ocimum Species Using Reverse Phase-High Performance Liquid Chromatography. Proceedings of the National Academy of Sciences, India Section B: Biological Sciences. 2016. Vol. 87, Issue 4. P. 1153-1158. doi: http://doi.org/10.1007/s40011-015-0682-y

16. Tartynska H. S., Zhuravel I. O., Kyslychenko V. S. Identyfikatsiia ta vyznachennia kilkisnoho vmistu tryterpenovykh ta steroidnykh spoluk talabanu polovoho (Thlaspi arvense L.) // Int. research and practice conf. Lublin, 2017. P. 139-142.

17. Determination of Oleanolic, Betulinic and Ursolic Acid in Lamiaceae and Mass Spectral Fragmentation of Their Trimethylsilylated Derivatives / Razborsek M. I. et. al. // Chromatographia. 2008. Vol. 67, Issue 5-6. P. 433-440. doi: http://doi.org/10.1365/s10337-008-0533-6

18. Marzouk A. M. Hepatoprotective Triterpenes from Hairy Root Cultures of Ocimum basilicum L // Zeitschrift Für Naturforschung C. 2009. Vol. 64, Issue 3-4. P. 201-209. doi: http://doi.org/10.1515/znc-2009-3-409

Рекомендовано до публікації д-р фарм. наук Гонтова Т. М. Дата надходження рукопису 10.05.2018

Shanaida Mariia, PhD, Associate Professor, Department of Pharmacognosy with Medical Botany, State Higher Educational Institution "I. Horbachevsky Ternopil State Medical University of Ministry of Health of Ukraine", Voli sq., 1, Ternopil, Ukraine, 46001

E-mail: shanayda@tdmu.edu.ua

Golembiovska Olena, PhD, Engineer, Department of Chemistry of Organic Sulfur Compounds, Laboratory of Condensed Heterocyclic Systems, Institute of Organic Chemistry, National Academy of Sciences of Ukraine, Murmanska str., 5, Kyiv, Ukraine, 02660

E-mail: golembiki@yahoo.fr 